\title{
STUDI KLINIK EFEK RAMUAN JAMU UNTUK INSOMNIA TERHADAP FUNGSI HATI PASIEN KLINIK HORTUS MEDICUS
}

\author{
Widhi Astana, Agus Triyono \\ Balai Besar Penelitian dan Pengembangan Tanaman Obat dan Obat Tradisional \\ J1. Raya Lawu No. 11 Tawangmangu Karanganyar Jawa Tengah \\ e-mail : $\underline{\text { drwidhiastana@gmail.com }}$
}

\begin{abstract}
ABSTRAK
Hati merupakan organ penting dalam tubuh manusia. Organ ini merupakan pusat metabolisme, salah satunya adalah metabolisme obat. Pengobatan konvensional yang menggunakan bahan kimia dapat menimbulkan perubahan pada fungsi hati. Sedangkan pada pengobatan tradisional, efek pengobatan pada fungsi hati masih jarang dipublikasikan. Salah satu penggunaan obat tradisional adalah jamu sebagai sedatif. Sebuah penelitian diadakan di Balai Besar Litbang Tanaman Obat dan Obat Tradisional (B2P2TOOT) tahun 2013 untuk mengetahui perubahan terhadap fungsi hati pasien-pasien yang mendapatkan terapi ramuan jamu insomnia. Penelitian berupa observasi terhadap 30 pasien insomnia yang datang dan berobat di Klinik Saintifikasi Jamu Hortus Medicus. Pasien insomnia yang mendapat terapi ramuan jamu selama 14 hari diobservasi fungsi hatinya. Evaluasi dilakukan pada nilai laboratoris yang merepresentasikan fungsi hati (SGOT dan SGPT) pada hari ke-0 dan hari ke-14. Perbandingan hasil pemeriksaan sebelum dan sesudah terapi menggambarkan perbedaan yang tidak bermakna kadar SGOT dan SGPT subjek penelitian( $p>0,05)$. Semua subjek memiliki nilai SGOT dan SGPT yang normal secara klinis dan laboratoris. Pemberian ramuan jamu untuk insomnia tidak mengganggu fungsi hati.
\end{abstract}

Kata kunci: insomnia, ramuan jamu, fungsi hati

\section{ABSTRACT}

Liver is the important organ of human. It is responsible to be metabolic organ, once of them is drug metabolism. Conventional treatment which use chemical agents may lead the change of liver function. In other hand, traditional medicine claims less of side effect but they still rarely observed. The using of any agents to treat insomnia for long time need advanced study of their safety, especially on the liver function. Previous study found that intervention of jamu formula containing leaves of several plants i.e. 5 gram of Leucas leuvandifolia, 5 gram of Centella asiatica, and 2 gram of Myristica fragrans reduced Insomnia Severity Index after 14 days treatment. The study was aimed to observe the effect of jamu formula on the liver functions of 30 insomnia patients. Conducted at the Klinik Saintifikasi Jamu "Hortus Medicus" B2P2TOOT, jamu formula was given to 30 patients at night for 14 days. The observation on the liver functions was done at day-0 and day-14 of intervention. The change of liver function was observed as indicated from the differences in the values of SGOT, SGPT of the patients before and after the intervention. After 14 days of the intervention, there is no significantly difference of the liver functions of the patients; their functions were at normal level. This means that the jamu formula does not interfere the function of the liver. 
Keywords: insomnia, jamu formula, liver function

\section{PENDAHULUAN}

Penggunaan obat dalam mengobati sebuah penyakit sering kali menimbulkan efek yang tidak diinginkan. Hal ini juga terjadi tidak terkecuali pada obat tradisional atau jamu. Salah satu organ yang sering mengalami perubahan karena metabolisme obat adalah hati. Organ hati adalah bagian terpenting dalam tubuh manusia yang sensitif terhadap efek toksik dari obat maupun preparat herbal. Menurut catatan, ada lebih dari 7000 kasusu kematian yang berhubungan dengan kerusakan hati karena obat. ${ }^{1}$ Penggunaan obat dosis tinggi atau jangka panjang dapat menimbulkan sel hati overload dengan lipid-soluble drug. Hal ini menimbulkan penurunan enzim spesifik dan mengurangi kecepatan metabolisme obat. Penurunan kecepatan metabolisme obat seringkali menyebabkan keracunan yang akhirnya menimbulkan kerusakan hati. ${ }^{2}$

Insomnia mempunyai gejalagejala seperti kesulitan memulai tidur, terbangun di tengah malam dan kesulitan untuk tidur lagi, bangun di pagi hari dengan badan yang tidak nyaman. Sebuah data berdasarkan penelitian internasional oleh biro sensus Amerika pada tahun 2004 menyatakan bahwa ketika populasi Indonesia pada 2004 sebanyak 238,452 juta, terdapat 28,053 juta masyarakat Indonesia menderita insomnia. Bila dihitung angka insidensinya adalah $11,7 \% .^{3}$ Insomnia bisa disebabkan oleh banyak hal, sehingga untuk mengobati secara efektif perlu kita ketahui penyebabnya. Ada beberapa terapi yang dikenal, dari terapi perilaku, konseling kejiwaan, psikoterapi, obat-obatan tradisional dan modern telah digunakan untuk terapi insomnia. ${ }^{4}$

Pada obat modern, menggunakan obat hipnotik untuk terapi jangka panjang dapat menyebabkan kecanduan. Di sisi lain, neuroleptik dan obat penenang yang tidak menyebabkan anestesi umum, meskipun penggunaan jangka panjang juga bisa terjadi kecanduan, ketergantungan fisik dan gangguan psikologis. ${ }^{5,6}$ Efek samping berbahaya dari obat-obatan modern yang mendorong orang untuk mencari alternatif yang lebih baik, terutama dalam hal farmakologi dan fitokimia dari obat-obatan tradisional yang dapat mengurangi stres, ketegangan dan insomnia dan telah digunakan secara empiris oleh masyarakat. Di Indonesia, orang jawa terutama mengenal jamu sebagai pengobatan tradisional yang telah digunakan turun-temurun. Ada beberapa tanaman dapat digunakan untuk meringankan insomnia seperti lenglengan, pegagan, pala, dan urang-aring. ${ }^{7}$ Penggunaan herbal (jamu) sebagai relaksan dan untuk menginduksi tidur telah dikenal sejak jaman kuno. Namun, studi tentang efek keamanan jamu tersebut masih jarang ditemukan. ${ }^{8}$ Jamu untuk insomnia yang terdiri dari daun lenglengan (Leucas leuvandifolia), herbal pegagan (Centella asiatica), dan pala (Myristica fragrans) telah digunakan dalam masyarakat di Jawa ancaman Insomnia $.9,10$

\section{Penelitian}

sebelumnya

menemukan bahwa intervensi ramuan jamu yang mengandung 5 gram daun lenglengan (Leucas leuvandifolia), 5 gram herba pegagan (Centella asiatica), dan 2 gram pala (Myristica fragrans) dapat mengurangi mengurangi Insomnia Severity Index subjek penelitian. ${ }^{11}$ Namun, tidak ada laporan tentang efek ramuan jamu pada fungsi hati. Oleh karena itu, penting untuk melakukan penelitian observasional untuk membuktikan keamanan ramuan jamu tersebut pada organ hati. 


\section{METODE PENELITIAN}

Studi ini menggunakan rancangan penelitian quasi experimental pre and post design dan berlokasi di klinik saintifikasi jamu Hortus Medicus Tawangmangu. Subjek pada studi klinis ini adalah 30 pasien yang menderita insomnia yang datang berobat di Klinik Saintifikasi Jamu "Hortus Medicus". Kriteria inklusinya: Penderita insomnia primer non-organik (F51.0 berdasarkan PPDGJ III); Status mental normal (melalui pemeriksaan status mental); Berumur 18 sampai 60 tahun. Kriteria eksklusinya : Subjek dengan mengkonsumsi obat hipnotik-sedatif lain yang dapat mempengaruhi observasi kurang dari 1 (satu) bulan; Subjek dengan komplikasi penyakit berat seperti jantung, kanker ( diketahui melalui catatan medis yang bersangkutan); Subjek dengan penyakit neurologis lain seperti parkinson, stroke, epilepsi, ( diketahui melalui catatan medis yang bersangkutan); Hipersensitivif terhadap jamu/obat herbal (secara umum) (didapat melalui anamnesis).

\section{Alat dan Bahan}

Simplisia ramuan jamu diambil dari kebun produksi Balai Besar Penelitian dan Pengembangan Tanaman Obat dan Obat Tradisional (B2P2TOOT) Tawangmangu. Determinasi dan standarisasi tanaman dilakukan di Laboratorium terpadu B2P2TOOT. Pembuatan bahan dan kontrol kualitas dilakukan oleh tim Quality Control (B2P2TO2T) Tawangmangu. Bahan dicuci dengan air yang mengalir untuk menghilangkan kotoran yang menempel, kemudian diangin-anginkan dilanjutkan pengeringan di dalam oven suhu 50 0C selama 7 jam. Simplisia kering dilakukan pengemasan dengan dosis 5 gram daun lenglengan, 5 gram daun pegagan dan 2 gram biji pala. Dosis tersebut di diminum sehari sekali menjelang tidur.

\section{Prosedur}

Pada awal studi, dilakukan pemeriksaan fungsi hati (SGOT dan SGPT). Pemeriksaan fungsi hati dilakukan pada awal dan pada akhir studi klinis, yaitu pada hari ke-0 dan pada hari ke-14. Pemeriksaan fungsi hati menggunakan semi-automatic photometer (Biolyzer 100, Germany). Darah subjek diambil melalui pembuluh vena cubiti, lalu disentrifuge dan diambil serumnya. Serum dicampur dengan reagen dan dibaca menggunakan alat Biolyzer Photometer. Mulai hari pertama intervensi (H1) subjek penelitian diberi ramuan jamu insomnia selama 14 hari. Jamu disiapkan dengan cara : 1 kantong jamu dimasukan dalam kuwali tanah, ditambahkan 2 gelas belimbing $(+400 \mathrm{ml})$ air dingin, dipanaskan dengan api kecil, setelah mendidih pemanasan dilanjutkan selama 15 menit, setelah itu diangkat dan didinginkan, setelah dingin disaring dan diminum pada malam hari pukul 6-7 malam selama 14 hari berturut turut.

Hasil pemeriksaan pada hari ke- 0 dan hari ke-14 dianalisis dengan uji $\mathrm{T}$ sampel berpasangan. Untuk memantau kepatuhan minum jamu, setiap subyek penelitian diberikan kartu kontrol minum jamu, dengan memberikan tanda pada kartu kontrol setiap minum jamu atau bila terlewat minum jamu.

\section{HASIL DAN PEMBAHASAN}

\section{Karakteristik subjek penelitian}

Sebanyak 30 subjek ikut serta dalam penelitian ini. Subjek laki-laki berjumlah 9 orang, sedangkan perempuan berjumlah 21 orang. Perempuan dua kali lebih rentan terkena insomnia karena ambang stres yang rendah. Semakin besar stres yang dirasakan akan meningkatkan kemingkinan terjadinya insomnia. ${ }^{5}$ Sebanyak 8 orang subjek insomnia berumur 31 sampai 40 tahun, 10 orang berusia 41 sampai 50 tahun, dan 12 orang berusia 51 sampai 60 tahun. Kejadian 
insomnia juga meningkat pada usia lanjut. ${ }^{5}$ Hasil pemeriksaan kadar ureum dan kreatinin subjek penelitian tertera pada tabel 1.

Tabel 1. Karakteristik subjek penelitian

\begin{tabular}{lll}
\hline & Karakteristik & Jumlah \\
\cline { 1 - 1 } Usia (tahun) & \\
\cline { 1 - 1 } - $31-40$ & 8 \\
- $41-50$ & 10 \\
- $51-60$ & 12 \\
\hline
\end{tabular}

\begin{tabular}{ll}
\hline Laki-laki & 9 \\
Perempuan & 21 \\
\hline
\end{tabular}

\section{Fungsi Hati (SGOT dan SGPT)}

Untuk melihat perbedaan fungsi hati sebelum dan sesudah intervensi, dilakukan pemeriksaan parameter fungsi hati (SGOT dan SGPT) sebanyak 2 kali. Pemeriksaan dilakukan pada hari ke-0 dan hari ke-14.

Tabel 2. Hasil pengukuran SGOT dan SGPT

\begin{tabular}{|c|c|c|c|c|}
\hline \multirow{2}{*}{ No Subjek } & \multicolumn{2}{|c|}{ SGOT } & \multicolumn{2}{|c|}{ SGPT } \\
\hline & Hari ke-0 & Hari ke -14 & Hari ke -0 & Hari ke -14 \\
\hline S-1 & 21 & 21 & 29 & 30 \\
\hline S-2 & 27 & 23 & 29 & 27 \\
\hline S-3 & 23 & 26 & 21 & 24 \\
\hline S-4 & 34 & 33 & 22 & 19 \\
\hline S-5 & 11 & 11 & 31 & 27 \\
\hline S-6 & 31 & 27 & 27 & 29 \\
\hline S-7 & 13 & 12 & 26 & 24 \\
\hline S-8 & 13 & 15 & 37 & 30 \\
\hline S-9 & 26 & 22 & 30 & 30 \\
\hline S-10 & 27 & 25 & 30 & 28 \\
\hline S-11 & 35 & 28 & 25 & 27 \\
\hline S-12 & 19 & 25 & 36 & 33 \\
\hline S-13 & 19 & 20 & 33 & 25 \\
\hline S-14 & 18 & 21 & 33 & 35 \\
\hline S-15 & 24 & 19 & 30 & 25 \\
\hline S-16 & 21 & 26 & 37 & 30 \\
\hline S-17 & 16 & 18 & 19 & 23 \\
\hline S-18 & 12 & 13 & 36 & 33 \\
\hline S-19 & 22 & 23 & 20 & 16 \\
\hline S-20 & 13 & 16 & 35 & 30 \\
\hline$S-21$ & 25 & 25 & 37 & 31 \\
\hline S-22 & 28 & 23 & 28 & 23 \\
\hline S-23 & 22 & 19 & 32 & 34 \\
\hline S-24 & 15 & 17 & 27 & 27 \\
\hline S-25 & 31 & 30 & 18 & 19 \\
\hline S-26 & 22 & 22 & 22 & 26 \\
\hline S-27 & 32 & 28 & 25 & 23 \\
\hline S-28 & 17 & 21 & 26 & 17 \\
\hline S-29 & 28 & 29 & 17 & 18 \\
\hline$S-30$ & 25 & 23 & 25 & 24 \\
\hline
\end{tabular}


Secara deskriptif, kadar SGOT subjek penelitian masih berada dalam batas normal. Rata-rata kadar SGOT subjek sebelum diintervensi jamu sebesar 22,33 U/l dengan standar deviasi sebesar 6,80 U/l. Rata-rata kadar SGOT setelah diintervensi jamu pada $\mathrm{H}-14$ sebesar 22,03 U/l dengan standar deviasi 5,40 U/1. Hasil uji $\mathrm{t}$ antara kadar SGOT pada $\mathrm{H}-0$ dan $\mathrm{H}-$ 14 , nilai $\mathrm{p}=0,31(>0,05)$ sehingga dapat disimpulkan tidak ada perbedaan yang bermakna kadar SGOT subjek sebelum dan sesudah intervensi pemberian jamu.

Hasil pemeriksaan SGPT subjek penelitian secara deskriptif ada sedikit penurunan kadar SGPT subjek sesudah intervensi pemberian jamu, namun nilai tersebut juga masih dalam batas normal. Rata-rata kadar SGPT subjek sebelum diintervensi jamu sebesar 28,10 U/l dengan standar deviasi sebesar 5,97 U/l. Rata-rata kadar SGPT subjek setelah diintervensi jamu pada $\mathrm{H}-14$ sebesar 26,23 U/l dengan standar deviasi 5,08 U/l. Pada H-56 rata-rata kadar SGPT menjadi 21,30 $\mathrm{u} / \mathrm{l}$ dengan standar deviasi 3,26 U/l. Hasil uji $\mathrm{t}$ antara kadar SGPT pada $\mathrm{H}-0$ dan $\mathrm{H}-$ 14 , nilai $\mathrm{p}=0,000(<0,05)$ sehingga dapat disimpulkan terdapat perbedaan yang bermakna SGPT sebelum dan sesudah intervensi pemberian jamu.

Hati adalah slah satu organ terpenting dalam tubuh manusia. Perbedaan nilai SGOT dan SGPT menjadi lebih tinggi merupakan salah satu parameter terjadinya kerusakan pada hati. ${ }^{1}$ Pada studi ini, tidak terdapat perbedaan yang signifikan pada SGOT sebelum maupun sesudah intervensi ramuan jamu. Sedangkan pada SGPT terdapat penurunan yang signifikan. Namun penurunan ini tidak mempengaruhi kondisi klinis subjek penelitian.

\section{KESIMPULAN}

Pemberian ramuan jamu
insomnia selama 14 hari
mempengaruhi fungsi hati. Jamu insomnia

dikategorikan sebagai jamu yang aman untuk digunakan pada pasien insomnia.

\section{UCAPAN TERIMA KASIH}

Penulis mengucapkan terima kasih kepada Balai Besar Penelitian dan Pengembangan Tanaman Obat dan Obat Tradisional Tawangmangu yang telah membiayai penelitian ini.

\section{DAFTAR PUSTAKA}

1. Almeida, S. M., C. S. Gama., N. Akamine. 2007. Prevalence and Calssification of drug-drug interaction in Intensive Care Patient. Einstein. 5(4):347- 351.

2. Remmer, H. 1970. The role of the liver in drug metabolism.The American Journal of Medicine Volume 49, Pages 617-629.

3. Guyton \& Hall. 1997. Aktivitas OtakTidur ; Gelombang Otak ; Epilepsy ; Psikosis. Dalam: Buku ajar fisiologi Kedokteran. Edisi 9. Jakarta : EGC.

4. Célyne H Bastien, Annie Vallières, Charles M Morin, 2001, Validation of the Insomnia Severity Index as an outcome measure for insomnia research. Journal of Sleep Medicine. http://www.sciencedirect.com/science /article/pii/S1389945700000654 accessed 14 agustus 2013

5. Kaplan, Sadock. Sinopsis psikiatri: ilmu pengetahuan perilaku psikiatri khas. Jilid satu. Edisi 7. Alih Bahasa: Widjaja Kusuma. Jakarta: Bina Putra Aksara; 199

6. Tjay, T., H., dan Rahardja, 2002, Obat-Obat Penting, Khasiat, Penggunaan dan Efek-Efek Sampingnya, Edisi Kelima, Direktur Jenderal Pengawasan Obat dan Makanan Departemen Kesehatan republik Indonesia, Jakarta.

7. Watanabe Taizo. 1995. Medical Herb Index in Indonesia. 2nd ed. Jakarta: PT. Eisai Indonesia.

8. Badan Penelitian dan Pengembangan Kesehatan. 2011. Vademekum 
Tanaman Obat. Jakarta: Badan Litbangkes. Kemenkes RI. Jakarta

9. Direktorat Jendral Pengawasan Obat dan Makanan. 2000. Acuan Sediaan Herbal. Depkes RI, Jakarta

10. Mardisiswoyo, S, Harsono R. 1968. Cabe puyang warisan nenek moyang, PT. Karya Wreda, cetakan IL.
11. Astana, P,W. 2013. Clinical Study of Jamu Formula for Insomnia Treatment. Study Report. Medical Plant and Traditional Medicine Research and Development Center.

12. Ronald A. Sacher, Richard A. McPherson. 2004. Tinjauan Klinis Hasil Pemeriksaan Laboratorium. Jakarta. EGC 